\title{
Identification of infants destined to die unexpectedly during infancy: evaluation of predictive importance of prolonged apnoea and disorders of cardiac rhythm or conduction
}

\author{
FIRST REPORT OF A MULTICENTRED PROSPECTIVE STUDY INTO THE SUDDEN \\ INFANT DEATH SYNDROME
}

\begin{abstract}
Twenty four hour tape recordings of electrocardiogram and breathing movement were made prospectively in 6914 full term and 2337 preterm infants or infants of low birth weight during their first six weeks of life. These recordings included 40 obtained in 29 infants who subsequently suffered the sudden infant death syndrome and 13 obtained in 10 other infants who died suddenly and unexpectedly.

None of the recordings obtained in the infants who suffered the sudden infant death syndrome showed prolonged apnoea (cessation of breathing movement for 20 seconds or more) or pre-excitation. One infant had multiple ventricular premature beats (38/hour). Compared with recordings obtained in 211 control infants who did not die none of the recordings obtained in the infants who suffered the syndrome showed abnormal prolongation of the QT interval.
\end{abstract}

\section{Introduction}

The sudden infant death syndrome- "the sudden death of any infant or young child which is unexpected by history and in which a thorough post mortem examination fails to demonstrate an adequate cause for death" results in about 1500 deaths a year in the United Kingdom (four a day) and 8000 deaths a year in the United States of America (22 a day). In one study the syndrome accounted for $45 \%$ of postperinatal infant deaths and $20 \%$ of all deaths from 8 days to 14 years of age and was second in incidence only to accidents as a cause of death in childhood. ${ }^{2}$

Previous attempts to identify the mechanisms behind the sudeen infant death syndrome have used results of postmortem examinations; physiological studies on infants who have previously suffered an episode of apnoea, cyanosis, or hypotonia ${ }^{3}$ (sometimes termed "near miss" sudden infant death syndrome); studies on siblings of victims of the syndrome; and experiments on animal models. The relative infrequency of the syndrome ${ }^{4}$ represents the main problem for prospective research, as 500 infants may have to be studied before data are available on one who subsequently dies.

The aim of this project was to collect, prospectively, clinical and physiological data on the cardiorespiratory function of infants who died suddenly and unexpectedly from any cause

Members of the study were: D P Southall (coordinator) (Cardiothoracic Institute, Brompton Hospital, London); J M Richards (Cardiothoracic Institute); $M$ de Swiet (Cardiothoracic Institute); W A Arrowsmith (Doncaster Royal Infirmary, Doncaster); J E Cree (Royal Sussex County Hospital, Brighton); P J Fleming (Bristol Maternity Hospital, Bristol); A J Franklin (St John's Hospital, Chelmsford); R L'E Orme (Royal Devon and Exeter Hospital, Exeter); M J Radford (Southampton General Hospital, Southampton); A J Wilson (Royal Hallamshire Hospital, Sheffield); D C Shannon (Massachusetts General Hospital, Boston, USA); J R Alexander (Thames Polytechnic, London); N J Brown (Bristol Royal Hospital for Sick Children, Bristol); E A Shinebourne (Cardiothoracic Institute).

Correspondence and requests for reprints to: Dr D P Southall, Cardiothoracic Institute, Brompton Hospital, Fulham Road, London SW3 6HP. (including the sudden infant death syndrome) and on unselected normal infants in the hope of yielding predictive criteria for the syndrome as well as clues to the mechanism of death. Physiological data were obtained from long term electrocardiographic recordings and recordings of breathing movement in large populations of infants. Two of the studies (see below) entailed screening preterm infants and infants of low birth weight, a group reported to have a higher risk of suffering the syndrome. ${ }^{2}$

This report of a preliminary analysis of the data addresses four questions: Do infants who subsequently suffer the sudden infant death syndrome show, on 24 hour recordings made in their first six weeks of life, episodes of prolonged cessation of breathing movement ( $\geqslant 20$ seconds), ventricular pre-excitation, cardiac arrhythmias, or prolongation of the QT interval?

\section{Patients and methods}

SIZE OF SAMPLE SUFFERING SUDDEN INFANT DEATH SYNDROME REQUIRED FOR ANALYSIS

A sample containing not fewer than 15 cases of the sudden infant death syndrome was calculated to be the minimum target of this project With $95 \%$ probability this sample would be expected to yield a minimum of two cases of the syndrome with abnormal recordings if the incidence of abnormal recordings in the syndrome was as low as $40 \%$, but should result in no more than one infant having an abnormal recording provided that the incidence of abnormal recordings in the total screened group did not exceed $1.5 \%$

POPULATIONS STUDIED

Study 1

Recordings were made in 6914 full term infants born in three maternity hospitals between July 1980 and July 1981 (table I).

Infants were studied in three hospitals with standards of neonatal care representative of those in the United Kingdom. Brighton and Doncaster hospitals provided a complete maternity service, and only infants born at home were not studied. Exeter has two maternity hospitals. One, served by family practitioners, provides care for uncomplicated pregnancies and was not included in this study. The Exeter sample was therefore biased to include firstborn infants and those from complicated pregnancies.

A total of 7388 infants were born in these centres between July 1980 and July 1981, and permission for participation in the study was obtained from the parents of $6914(94 \%)$ infants. Seven per cent of recordings contained less than 12 hours of either the electrocardiogram or breathing movement; $56 \%$ of these failed recordings were successfully repeated.

In Brighton and Doncaster two recordings were performed in each infant, one during the first week of life (avoiding the first 24 hours after birth) and the second at home at around 6 weeks of age. In Exeter a single recording was made at around 6 weeks of age, except in infants who had been treated in the neonatal intensive care unit, in whom one recording was performed just before discharge from the unit and a second at home six weeks later. At the end of the project a few infants in Doncaster and Brighton underwent a single recording between 2 and 4 weeks of age.

Follow up studies were planned six weeks later for 5677 of the 6914 infants in whom first recordings had been obtained. Parental refusal or movement of families from the area prevented a second recording in $1551(27 \%)$ of these infants (table I). 
By January 1983, 21 infants had died suddenly and unexpectedly (table II). Thirteen suffered the sudden infant death syndrome (an incidence of $1 \cdot 76 / 1000$ full term births). In three infants it was impossible from the history or postmortem findings to know whether the cause of death given was appropriate (recorded as bronchopneumonia in two and chickenpox in the third). Five deaths were probably adequately explained. Eleven of the 13 infants who suffered the syndrome had undergone tape recordings (table III, cases 1-11).

\section{Study 2}

Recordings were made in 1138 preterm infants ( $<37$ weeks) or infants of low birth weight $(\leqslant 2500 \mathrm{~g}$ ) on discharge from six neonatal intensive care units between July 1979 and September 1980.
This study has already been reported in detail. ${ }^{5}$ All tapes were analysed immediately after recording for prolonged apnoea ( $>30$ seconds); this analysis resulted in one infant receiving treatment and five undergoing apnoea monitoring. Six infants subsequently died suddenly and unexpectedly, including five categorised as suffering the sudden infant death syndrome (table III, cases 12-16).

\section{Study 3}

Recordings were made in 1199 preterm infants ( $<37$ weeks) or infants of low birth weight $(\leqslant 2500 \mathrm{~g})$ on discharge from six maternity hospitals between September 1980 and December 1981 (table IV).

In three centres-Brighton, Doncaster, and Exeter-all preterm and low birth weight infants were enrolled in the study (843 infants).

TABLE I-Details of full term infants undergoing recordings (1 fuly 1980 to 31 fuly 1981)

\begin{tabular}{|c|c|c|c|c|c|c|}
\hline Centre & $\begin{array}{l}\text { Population } \\
\text { born }\end{array}$ & $\begin{array}{l}\text { Age at first } \\
\text { recording }\end{array}$ & $\begin{array}{l}\text { No of first } \\
\text { recordings } \\
\text { obtained }\end{array}$ & $\begin{array}{c}\text { No of } \\
\text { refusals }\end{array}$ & $\begin{array}{l}\text { No of follow up } \\
\text { recordings } \\
\text { obtained }\end{array}$ & $\begin{array}{l}\text { No of refusals } \\
\text { for follow up } \\
\text { recordings }\end{array}$ \\
\hline Brighton & 2630 & $\left\{\begin{array}{r}<2 \text { weeks } \\
2-4 \text { weeks }\end{array}\right.$ & $\begin{array}{r}2294 \\
60\end{array}$ & $\left.\begin{array}{r}263 \\
13\end{array}\right\} 10 \%$ & $\begin{array}{l}1462(64 \%) \\
\text { NA }\end{array}$ & 832 \\
\hline Doncaster & 3506 & $\left\{\begin{array}{l}2 \text { weeks } \\
2-4 \text { weeks }\end{array}\right.$ & $\begin{array}{r}3314 \\
94\end{array}$ & $\left.\begin{array}{l}77 \\
21\end{array}\right\} 3 \%$ & $\begin{array}{l}2599(78 \%) \\
\text { NA }\end{array}$ & 715 \\
\hline Exeter & 1252 & $\left\{\begin{array}{l}1-4 \text { weeks* } \\
5-7 \text { weeks }\end{array}\right.$ & $\begin{array}{r}69 \\
1083\end{array}$ & $\left.\begin{array}{r}0 \\
100\end{array}\right\} 8 \%$ & $\begin{array}{l}65(94 \%) \\
\mathrm{NA}^{5}\end{array}$ & 4 \\
\hline Totals & 7388 & & $6914(94 \%)$ & $474(6 \%)$ & $4126(73 \%) \dagger$ & 1551 \\
\hline
\end{tabular}

*Before discharge from special care baby unit. †Proportion of infants assigned for follow up recordings.

$\mathrm{NA}=$ No attempt made to obtain follow up recordings.

TABLE II-Details of sudden and unexpected deaths in full term infants (study 1) notified by 1 fanuary 1983

\begin{tabular}{|c|c|c|c|c|c|}
\hline Centre & $\begin{array}{c}\text { No of } \\
\text { infants } \\
\text { born }\end{array}$ & $\begin{array}{c}\text { No of } \\
\text { sudden } \\
\text { unexpected } \\
\text { infant } \\
\text { deaths }\end{array}$ & No adequately explained & No with indefinite explanation & $\begin{array}{l}\text { No (and incidence) } \\
\text { of cases of sudden } \\
\text { infant death } \\
\text { syndrome }\end{array}$ \\
\hline $\begin{array}{l}\text { Brighton } \\
\text { Doncaster }\end{array}$ & $\begin{array}{l}2630 \\
3506\end{array}$ & $\begin{array}{r}3 \\
13\end{array}$ & $\begin{array}{l}\text { 2: one with undiagnosed congenital heart } \\
\text { disease (univentricular heart); one with } \\
\text { fractured skull (road traffic accident) }\end{array}$ & $\begin{array}{l}2: \text { one with bronchopneumonia (undetected } \\
\text { by parents); one with epileptic convulsion } \\
\text { (previous meningitis with residual brain } \\
\text { damage) }\end{array}$ & $\begin{array}{l}3(1 \cdot 11 / 1000) \\
9(2 \cdot 57 / 1000)\end{array}$ \\
\hline Exeter & 1252 & 5 & $\begin{array}{l}\text { 3: one with undiagnosed congenital heart } \\
\text { disease (multiple pulmonary artery } \\
\text { stenoses, aortic and pulmonary outflow } \\
\text { tract hyperplasia); one with undiagnosed } \\
\text { endocardial fibroelastosis; one with } \\
\text { asphyxia after inhalation of a foreign body }\end{array}$ & $\begin{array}{l}1: \text { intractable epilepsy of unknown origin, } \\
\text { with chickenpox }\end{array}$ & $1(0 \cdot 80 / 1000)$ \\
\hline Totals & 7388 & 21 & 5 & 3 & $13^{*}(1 \cdot 76 / 1000)$ \\
\hline
\end{tabular}

*Eleven $(85 \%)$ underwent tape recordings (cases $1-11$, table III).

TABLE III-Summary of results of recordings made on 29 infants who subsequently suffered sudden infant death syndrome

\begin{tabular}{|c|c|c|c|c|c|}
\hline $\begin{array}{l}\text { Case } \\
\text { No }\end{array}$ & $\begin{array}{l}\text { Birth weight } \\
\text { maturity }\end{array}$ & $\begin{array}{l}\text { Age(s) at } \\
\text { recording(s) } \\
\text { (days) }\end{array}$ & $\begin{array}{l}\text { Age at death } \\
\text { (weeks) } \\
\text { (and days) }\end{array}$ & $\begin{array}{l}\text { Longest episode of apnoea } \\
\text { on each recording } \\
\text { (s) }\end{array}$ & $\begin{array}{l}\text { Arrhythmia or } \\
\text { pre-excitation }\end{array}$ \\
\hline 1 & Full term; small for dates & 5,47 & $15(108)$ & $9 \cdot 6,9 \cdot 6$ & None \\
\hline 2 & Full term & 6 & $34(237)$ & $8 \cdot 4$ & , \\
\hline$\overline{3}$ & Full term & 2 & $5(39)$ & $12 \cdot 0$ & ”, \\
\hline 4 & Full term; small for dates & 8,52 & $21(148)$ & $7 \cdot 2,9 \cdot 6$ & ", \\
\hline 5 & Full term & 24,63 & $10(74)$ & $10 \cdot 8,8 \cdot 4$ & "” \\
\hline 6 & Full term (twin) & 5,40 & $23(159)$ & $9 \cdot 6,7 \cdot 2$ & "” \\
\hline 7 & Full term & & $25(175)$ & $13 \cdot 2$ & "” \\
\hline 8 & Full term & 3,41 & $16(112)$ & $8 \cdot 4,7 \cdot 2$ & ” \\
\hline 9 & Full term & 19,61 & $13(95)$ & $8 \cdot 4,7 \cdot 2$ & ", \\
\hline 10 & Full term & 40 & $12(87)$ & $6 \cdot 0$ & ", \\
\hline 11 & Full term; small for dates & 2 & $65(457)$ & $12 \cdot 0$ & "” \\
\hline 12 & Preterm (twin)* & 8 & $31(220)$ & $9 \cdot 6$ & ”" \\
\hline 13 & Preterm* & 69 & $13(93)$ & 9.6 & "” \\
\hline 14 & Preterm* & 43 & $15(105)$ & $10 \cdot 8$ & ", \\
\hline 15 & Preterm* & 25 & $24(169)$ & $10 \cdot 8$ & , \\
\hline 16 & Full term; small for dates* & 6 & $10(73)$ & $12 \cdot 0 \dagger$ & ", \\
\hline $\begin{array}{l}17 \\
18\end{array}$ & $\begin{array}{l}\text { Preterm; small for dates* } \\
\text { Preterm** }\end{array}$ & $\begin{array}{l}2,48 \\
44\end{array}$ & $\begin{array}{l}8(54) \\
8(59)\end{array}$ & $\begin{array}{l}9 \cdot 6,10 \cdot 8 \\
12 \cdot 0\end{array}$ & Ventricular premature \\
\hline 19 & Full term; small for dates* & & $9(65)$ & & $\begin{array}{l}\text { beats } 38 / \mathrm{h} \\
\text { None }\end{array}$ \\
\hline 20 & Preterm (twin)* & $37,58,61$ & $29(203)$ & $10 \cdot 8,13 \cdot 2,10 \cdot 8$ & , 2 \\
\hline 21 & Full term; small for dates (twin)* & 16 & $43(303)$ & $10 \cdot 8$ & ” \\
\hline 22 & Preterm (twin)* & 39 & $9(61)$ & $13 \cdot 2$ & ” \\
\hline 23 & Preterm* & 87 & $14(96)$ & $9 \cdot 6$ & "” \\
\hline 24 & Full term; small for dates* & 11 & $3(27)$ & $13 \cdot 2$ & ”" \\
\hline 25 & Preterm; small for dates* & 15,65 & $41(285)$ & $12 \cdot 0,10 \cdot 8$ & ” \\
\hline 26 & Full term + & 133,134 & $21(150)$ & No respiratory recording & " \\
\hline 27 & Full term; small for dates + & 16 & $3(27)$ & $10 \cdot 8$ & ” \\
\hline 28 & Preterm* & 144 & $24(167)$ & $9 \cdot 6$ & "” \\
\hline 29 & Preterm; small for dates* & 38 & $13(88)$ & $9 \cdot 6 \dagger$ & ” \\
\hline
\end{tabular}

Small for dates $=$ less than 10 th centile.
*First recording made before discharge from neonatal unit. $\nmid$ Less than 12 hours of adequate breathing signals. $\ddagger$ Previous near miss episode. 
TABLE IV-Details of preterm infants and infants of low birth weight studied, September 1980 to December 1981

\begin{tabular}{|c|c|c|c|c|c|c|c|}
\hline Centre & $\begin{array}{l}\text { Population } \\
\text { born }\end{array}$ & No of refusals & $\begin{array}{l}\text { No of failed } \\
\text { recordings } \\
\text { (No successfully } \\
\text { repeated) }\end{array}$ & $\begin{array}{l}\text { No of successful } \\
\text { first recordings }\end{array}$ & $\begin{array}{l}\text { No of infants } \\
\text { having follow up } \\
\text { recordings }\end{array}$ & $\begin{array}{l}\text { No of sudden } \\
\text { unexpected infant } \\
\text { deaths }\end{array}$ & $\begin{array}{l}\text { No with sudden } \\
\text { infant death } \\
\text { syndrome* }\end{array}$ \\
\hline $\begin{array}{l}\text { Brighton } \\
\text { Doncaster }\end{array}$ & $\begin{array}{l}166 \\
406\end{array}$ & $\begin{array}{l}5 \\
7\end{array}$ & $\begin{array}{c}8(6) \\
27(12)\end{array}$ & $\begin{array}{l}159 \\
384\end{array}$ & $\begin{array}{r}94 \\
224\end{array}$ & 2 & 2 \\
\hline Exeter & 271 & 5 & $22(7)$ & 251 & 109 & 2 & 2 \\
\hline Total† & 843 & 17 & & $794(94 \%)$ & $427(51 \%)$ & 4 & $4(4 \cdot 74 / 1000)$ \\
\hline Chelmsford & 56 & 5 & $4(0)$ & 47 & 7 & 2 & 2 \\
\hline $\begin{array}{l}\text { Southampton } \\
\text { Bristol }\end{array}$ & $\begin{array}{r}37 \\
348\end{array}$ & 14 & $\begin{array}{r}1(0) \\
16(4)\end{array}$ & $\begin{array}{r}36 \\
322\end{array}$ & $\begin{array}{l}10 \\
29\end{array}$ & $\begin{array}{l}1 \\
3\end{array}$ & $\begin{array}{l}1 \\
3\end{array}$ \\
\hline Totalt & 441 & 19 & & $405(92 \%)$ & $46(10 \%)$ & 6 & 6 \\
\hline Overall total & 1284 & $36(2 \cdot 8 \%)$ & & $1199(93 \%)$ & $473(37 \%)$ & 10 & 10 \\
\hline
\end{tabular}

*Cases 17-25 in table III (one did not undergo a tape recording before death). †“Population-based” data. ¥ $¥$ Selected cases.

In Bristol, Chelmsford, and Southampton only infants cared for and discharged from the neonatal intensive care unit were studied (441 infants). Parents of $36(2.8 \%)$ of the 1284 infants enrolled in the project (table IV) refused to allow recordings.

First recordings were made when infants were considered to be well and within one week before discharge from the neonatal intensive care unit or the postnatal ward. A second recording was performed at home roughly six weeks later in $473(37 \%)$ infants. Seventy eight $(6 \%)$ of the first recordings contained less than 12 hours of either the electrocardiogram or breathing movement; $29(37 \%)$ of these recordings were successfully repeated.

A total of 1672 successful 24 hour recordings were made in 1199 infants. At 1 January 1983, 10 infants from this population had died suddenly and unexpectedly; all were categorised as suffering the sudden infant death syndrome. In the "population based" sample of 843 infants studied four suffered the syndrome (an incidence of $4 \cdot 74 / 1000$ )

Owing to an oversight a 24 hour recording was not performed in one of the infants who suffered the syndrome. Thirteen recordings were obtained in the remaining nine cases (table III, cases 17-25).

\section{Study 4}

Twenty four hour recordings were obtained in five infants who subsequently died suddenly and unexpectedly but were not part of the population based studies.

Two infants out of 164 (one sided $95 \%$ confidence interval $0-38 / 1000$ ) who had suffered an episode of apnoea, cyanosis, or hypotonia (sometimes termed "near miss" sudden infant death syndrome $^{3}$ ) and were referred to the Brompton Hospital for 24 hour tape recordings after routine investigations had failed to identify a cause subsequently died suddenly and without adequate cause of death at necropsy (table III, cases 26 and 27).

Three preterm infants from hospitals other than those in studies 2 and 3 also underwent 24 hour recordings before dying suddenly and unexpectedly (two deaths were categorised as the sudden infant death syndrome (table III, cases 28 and 29) and one as bronchopneumonia).

IDENTIFICATION OF INFANTS DYING SUDDENLY AND UNEXPECTEDLY, AND INVESTIGATIONS INTO CAUSES OF DEATH

All coroners and pathologists in the areas of the study were asked to notify infant deaths. To ensure as far as possible that all deaths in the population were identified, including those in families who might have moved out of the area, the records of the infants, including those whose parents had refused a tape recording, were tagged at the Department of Health and Social Services. A copy of the death certificate of any such infant dying in the United Kingdom was supplied within four months of the death.

The pathologists in the study centres were practised in performing postmortem examinations on infarits and used protocols that included careful histological and microbiological studies. In addition, an independent paediatric pathologist (NJB) reviewed the findings of the local pathologist. This review, which included a detailed examination of the histological findings, was undertaken in all but three cases, in which death occurred in an area outside that in which the infant was born; in these cases a postmortem examination that did not include histological studies was performed. When possible the parent(s) of infants dying suddenly and unexpectedly were interviewed at home by DPS usually between one and two months after their baby's death, resulting in home visits in 20 of the 29 cases of the sudden infant death syndrome. A consensus on the most appropriate cause of death was then obtained at a case conference between pathologists, the local paediatrician, and the project coordinator (DPS).

\section{METHODS OF RECORDING}

Recordings were made using a Medilog 1 four channel battery operated tape recorder (Oxford Medical Systems). The electrocardiogram was recorded on to channel one from two pregelled electrodes placed in a modified lead II position on the infant's chest wall. In all but a few cases in the first study, when impedance pneumography was used, ${ }^{5}$ the breathing movement was obtained from a pressure capsule $^{6}$ taped to the infant's abdominal wall midway between the umbilicus and the xiphisternum with concentric strips of Micropore tape. Time varying pressure changes within the capsule were converted to a time varying electrical signal and recorded on to channel two of the tape recorder. Channel three was a device for improving the "signal to noise" ratio of the breathing movement signal, ${ }^{7}$ and on channel four a $60 \mathrm{~Hz}$ crystal controlled clock signal provided a time base for accurate measurements when the tapes were replayed.

\section{ADDITIONAL DATA COLLECTED}

Infant activity was logged by parents and nurses during each recording, and, when possible, full details of pregnancy and postnatal history were compiled at the time of the recording.

\section{METHODS OF DATA ANALYSIS}

Immediately after recording, tapes were checked for quality. If there was less than 12 hours of either breathing or electrocardiogram an attempt was made to repeat the recording. To identify a known and treatable cause of sudden death, the long QT syndrome, ${ }^{8}$ a single 10 second section of the electrocardiogram from each tape was chosen at random and examined. Any infants in whom the QT interval exceeded 0.40 seconds were referred to their paediatrician. Tapes were then stored without further analysis (except in study $2^{5}$ ) and examined in more detail only after infants had reached 1 year of age (as controls) or after death.

Three analyses were made of the recordings obtained in victims of the sudden infant death syndrome.

Firstly, in addition to measuring the QT interval, which was done in all infants, the QT interval and corresponding heart rate were measured in a single 10 second section selected from a position in the recording when the R-R interval was 0.40 seconds or over. Since the frequency response of the electrocardiographic amplifiers within the tape recorder were different from those in standard electrocardiographic machines (standard machine $0.05-100 \mathrm{~Hz} ; 24$ hour Medilog $0.5-50 \mathrm{~Hz}$ ) it was difficult to compare results obtained in the victims of the sudden infant death syndrome with those obtained in other studies. The ST segment of the electrocardiographic complex was longer, and the shape of the $T$ wave varied with the filters used with the replay system. New reference levels were therefore produced by measuring QT intervals in 142 full term and 69 preterm, randomly selected surviving controls (also from positions in the tape where the $\mathrm{R}-\mathrm{R}$ interval was 0.40 seconds). 
Figures 1 and 2 show the distribution with age of the QTc values (QT interval divided by the square root of the immediately preceding $\mathrm{R}-\mathrm{R}$ interval) in both controls and cases of the sudden infant death syndrome.

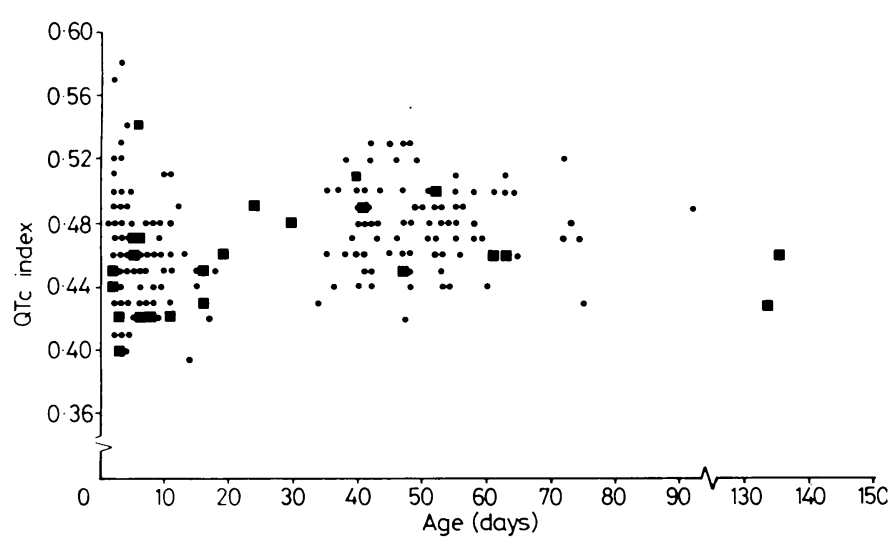

FIG $1-\mathrm{QTc}$ index in 24 recordings obtained from 17 full term infants who suffered the sudden infant death syndrome ( $\boldsymbol{D}$ ) and 142 full term controls (O) plotted against postnatal age. (There were no apparent differences in the index between cases and controls.)

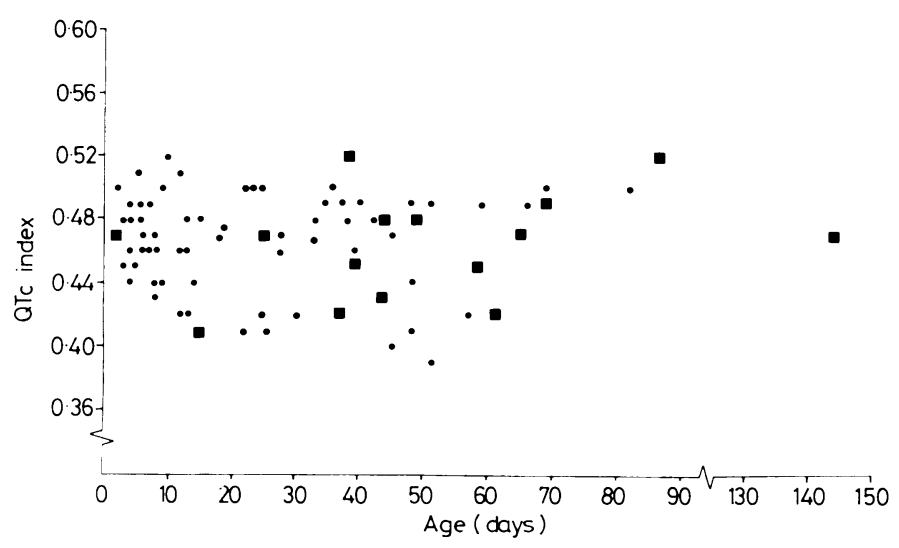

FIG 2-QTc index in 15 recordings obtained in 11 preterm infants who suffered the sudden infant death syndrome $(\square)$ and 69 controls $(\bullet)$ plotted against postnatal age. (There were no apparent differences in the index between cases and controls.)

Secondly, the whole of each recording was examined for cardiac arrhythmias or pre-excitation using preset $\mathrm{R}-\mathrm{R}$ interval discriminants and a high speed analyser (Oxford Medical Systems).

Thirdly, each recording was printed out at 60 times the recording speed on to paper with an ink jet recorder (Siemens Mingograf 34T). From this printout the longest episode of cessation of breathing movement was measured manually.

Since the definition of apnoea is "the absence of air flow into the lungs" we must emphasise that only episodes resulting from an absence of breathing movements would have been identified by this recording technique (so called central apnoea ${ }^{9}$ ). Apnoea due to obstruction of the airway ${ }^{9}$ with continued breathing movements would not have been detected.

\section{Results}

A total of 40 tape recordings were made in the 29 infants (17 full term, 12 preterm) who subsequently suffered the sudden infant death syndrome (table III). None of these 29 infants had prolonged cessation of breathing movements (central apnoea $\geqslant 20$ seconds), the longest apnoeic pause in this group being 13.2 seconds. One preterm infant (case 18) had multiple ventricular premature beats of parasystolic origin (38/hour). No infant showed ventricular pre-excitation.

Figures 1 and 2 show that none of the recordings obtained in 28 of the 29 infants who suffered the sudden infant death syndrome had a prolonged QTc index compared with those obtained in the controls. In one case (case 12, table III) the ST segment of the waveform was obscured by artefact and the QT interval could not be measured.

The one sided $95 \%$ confidence interval for the proportion of infants who suffered the sudden infant death syndrome and had prolonged central apnoea, ventricular pre-excitation, or a prolonted QTc index on a 24 hour recording was $0-10 \%$; for multiple ventricular premature beats of parasystolic origin it was $0-15 \%$. Hence these abnormalities could in no way be predictive of the sudden infant death syndrome except in a very small proportion of cases.

\section{Discussion}

This study has provided a unique collection of physiological and clinical data on 29 infants who subsequently suffered the sudden infant death syndrome and similar information on a large population of children surviving infancy. The latter, apart from providing a baseline control group for infants who die, will permit investigations into possible relations between neonatal cardiorespiratory patterns and other developmental abnormalities that may occur, or become apparent, later in childhood.

To some extent the preliminary findings of this study were disappointing. The sudden infant death syndrome was not predicted by measurements of the longest episode of central apnoea or a simple measurement of the QT interval from a 24 hour electrocardiogram. Analysis of the recordings also failed to show a predictive relation between cardiac arrhythmias or ventricular pre-excitation and the syndrome. These negative findings do, however, have important clinical consequences.

Roughly $1 \%$ of apparently healthy newborn infants have cardiac arrhythmias or ventricular pre-excitation on recordings of the standard electrocardiogram. ${ }^{1011}$ Some arrhythmias detected have been associated with sudden death in older children. ${ }^{12}$ Aberrant pathways bypassing the atrioventricular node, providing a potential for ventricular pre-excitation, have also been identified after death in some cases of the sudden infant death syndrome. ${ }^{13} 14$ The hypothesis that cardiac arrhythmias or abnormalities of cardiac conduction in apparently healthy infants might place some at increased risk of the syndrome required testing. Only one of the 29 infants who subsequently died had an arrhythmia on the 24 hour recording. Since the incidence of this particular arrhythmia is $8 / 1000^{5}$ it could have been present by chance rather than by direct association with this infant's death. Most cardiac arrhythmias occurring in otherwise well infants therefore do not increase the risk of them suffering the sudden infant death syndrome.

Prolonged ventricular repolarisation (lengthening of the QT interval on the electrocardiogram) has long been recognised as a predictor of sudden death in older children and young adults. ${ }^{15}$ Between 1976 and 1978 several papers were published on the possible relation between prolongation of the QT interval and the sudden infant death syndrome. These reports, based on studies of siblings and other relatives of victims of the syndrome $^{16-18}$ and on infants who had suffered a near miss episode, ${ }^{19-21}$ produced conflicting results. In 1979 an infant with a QT interval of 0.52 seconds (QTc 0.63 ) in the first week of life died suddenly and unexpectedly, providing definite evidence that the long QT syndrome may be one cause of the sudden infant death syndrome, ${ }^{8}$ and a recent prospective study reported one case of sudden death in infancy in which the QT interval was prolonged in the neonatal period. ${ }^{22}$ Prolonged ventricular repolarisation may therefore be one cause of sudden death in infancy, but the proportion of cases of the sudden infant death syndrome resulting from this problem has not been assessed. Analysis of the QT interval in 24 hour recordings showed that intervals in controls (normal infants) were more prolonged than reference values obtained from standard electrocardiographic data, ${ }^{22}$ a phenomenon related to the different frequency response of the electrocardiographic amplifiers in the tape recorder (see above). Nevertheless, none of the infants who suffered the sudden infant death syndrome showed prolonged intervals compared with control values obtained with the Medilog 
recorder; this indicates that a single measurement of the QT interval from the 24 hour recording was not predictive of the syndrome. Conceivably, though in our opinion it is unlikely, a difference between infants who died and controls was masked by the use of different electrocardiographic amplifiers. A further prospective study using standard electrocardiographic recorders is probably indicated.

Many studies of infants who have suffered a near miss episode ${ }^{23-27}$ and one study of siblings of victims of the sudden infant death syndrome ${ }^{28}$ have suggested a relation between disorders in ventilatory control and the syndrome. Undetected prolonged apnoeic episodes have also been detected in a small proportion of preterm infants at the time of discharge from hospital. ${ }^{5}$ Though none of the infants who suffered the sudden infant death syndrome in this study showed prolonged central apnoea ( $\geqslant 20$ seconds) on their recordings, further studies on respiratory patterns rather than just the longest apnoeic episode are needed before any conclusions can be made regarding respiratory control and prediction of the sudden infant death syndrome.

In conclusion, the sudden infant death syndrome was not predicted by the presence of prolonged apnoea or disorders of cardiac rhythm or conduction on 24 hour tape recordings taken during the first six weeks of life; these results neither confirm nor negate the possibility that these disorders occur just before death in this syndrome. This study does suggest, however, that prolonged apnoea sometimes detected after a near miss episode may be the consequence of the episode rather than the cause. The next phase of this study entails a more detailed examination of the heart rate and breathing patterns of infants who suffer the sudden infant death syndrome and controls in the hope that clues predicting infants at increased risk may be identified.

We thank the research team who performed recordings and collected clinical data; the coroners and local health authorities; Mrs J Gallagher and the birth and death registry at the Department of Health and Social Services; the pathologists in the centres; and Susan Alexander and Jill Bryant for secretarial help.

This project was funded for the most part by large and generous grants from the British Heart Foundation. Additional major funding was provided by the Foundation for the Study of Infant Deaths, the Medical Research Council, donations from the people of Doncaster, and the Bumble Fund.

\section{References}

1 Beckwith JB. Discussion of terminology and definition of sudden infan death syndrome. In: Bergman AB, Beckwith JB, Ray CG, eds. Proceedings of the second international conference on causes of sudden death in infants, Seattle, 1970. Washington: University of Washington Press, 1970:14-22.

${ }^{2}$ Bergman AB, Ray CG, Pomeroy MA, Wahl PW, Beckwith JB. Studies of the sudden infant death syndrome in King County, Washington. III. Epidemiology. Pediatrics $1971 ; \mathbf{4 9 : 8 6 0 - 7 0}$

${ }^{3}$ Kahn A, Blum D. Home monitoring of infants considered at risk for the sudden infant death syndrome. Eur 7 Pediatr 1982;139:94-100.

4 Shannon DC, Kelly DH. SIDS and near SIDS. N Engl f Med 1982;306 959-65.

${ }^{5}$ Southall DP, Richards JM, Rhoden KJ, Shinebourne EA. Prolonged apnoea and cardiac arrhythmias in infants discharged from neonatal intensive care units; failure to predict an increased risk for SIDS. Pediatrics 1982;70:844-51.

${ }^{6}$ Wright BM, Callan K. A new respiratory recording and monitoring system. In: Stott FD, Raftery EB, Goulding L, eds. Proceedings of the 3 rd international symposium on ambulatory monitoring. London: Academic Press, 1980:329-34

7 Wilson AJ, Brown BH. A simple wideband compander system for biological signals. Med Biol Eng Comput 1982;20:512-6.

* Southall DP, Arrowsmith WA, Oakley JR, McEnery G, Anderson RH, Shinebourne EA. Prolonged QT interval and cardiac arrhythmias in 2 neonates; sudden infant death syndrome in one case. Arch Dis Child 1977;54:776-9.

9 Guilleminault C, Peraita R, Souquet M, Dement WC. Apneas during sleep in infants: possible relationship with sudden infant death syndrome. Science 1975;190:677-9.

10 Southall DP, Johnson AM, Shinebourne EA, Johnston PGB, Vulliamy DG. Frequency and outcome of disorders of cardiac rhythm and conduction in a population of newborn infants. Pediatrics $1981 ; 68: 58-66$
11 Jones RWA, Sharp C, Rabb LR, Lambert BR, Chamberlain DA. 1028 neonatal electrocardiograms. Arch Dis Child 1979;54:427-31.

12 Radford DJ, Izukawa T, Rowe RD. Evaluation of children with ventricular arrhythmias. Arch Dis Child 1977;52:345-53.

${ }_{13}$ Anderson RH, Boulton J, Burrow CT, Smith A. Sudden death in infancy a study of cardiac specialised tissue. $\mathrm{Br} M e d \mathcal{F} 1974$;ii:135-9.

14 Lipsitt LP, Sturner WQ, Oh W, Barrett J, Truex RC. Wolff-ParkinsonWhite and sudden infant death syndromes. N Englf Med 1979;300:1111.

15 Schwartz PJ. The long QT syndrome. In: Kulbertus HE, Wellens $\mathrm{HJJ}$ eds. Sudden death. The Hague: Martinus Nijhoff, 1980:358-78.

16 Maron BJ, Clark CE, Goldstein RE, Epstein SE. Potential role of QT interval prolongation in sudden infant death syndrome. Circulation 1976;54:423-30.

17 Kukolich MK, Telsey A, Ott J, Motulsky AG. Sudden infant death syndrome: normal QT interval on ECGs of relatives. Pediatrics 1977; 60:51-4.

18 Steinschneider A. Sudden infant death syndrome and prolongation of the QT interval. Am 7 Dis Child 1978;132:688-91.

19 Ferrer PL, Jesse MJ. Prolonged QT index in "near-miss" sudden death in infancy [Abstract]. Clinical Research 1977;25:64a

${ }^{20}$ Kelly DH, Shannon DC, Liberthson RR. The role of the QT interval in the sudden infant death syndrome. Circulation 1977;55:633-5.

${ }^{21}$ Haddad GG, Epstein MAF, Epstein RA, Mazza NM, Mellins RB, Krongrad $\mathrm{E}$. The QT interval in aborted SIDS infants. Pediatr Res 1978;13:135-8.

${ }^{22}$ Schwartz PJ, Montemerlo M, Facchini M, et al. The QT interval throughout the first six months of life: a prospective study. Circulation 1982; 66:496-501.

${ }^{23}$ Shannon DC, Kelly DH, O'Connell K. Abnormal regulation of ventilation in infants at risk for the sudden infant death syndrome. $N$ Engl $7 \mathrm{Med}$ 1977;297:747-50.

24 Steinschneider A. Prolonged apnoea and the sudden infant death syndrome: clinical and laboratory observations. Pediatrics 1972;50:646-54

25 Guilleminault $C$, Ariagno $R$, Souquet $M$, Dement WC. Abnormal polygraphic findings in near-miss sudden infant death. Lancet 1976; : 1326-7.

${ }^{26}$ Southall DP, Richards JM, Brown DJ, Johnston PGB, de Swiet M, Shinebourne EA. 24-hour tape recordings of ECG and respiration in the newborn infant with findings related to sudden death and unexplained brain damage in infancy. Arch Dis Child 1980;55:7-16.

27 Kelly DH, Shannon DC. Periodic breathing in infants with near-miss SIDS. Pediatrics 1979;63:355-60.

${ }^{28}$ Kelly DH, Walker AM, Cahen L, Shannon DC. Periodic breathing in siblings of sudden infant death syndrome victims. Pediatrics $1980 ; 66$. 515-20.

(Accepted 8 February 1983)

ONE HUNDRED YEARS AGO Many wearied and wakeful persons find in the howling of dogs by night a persistent, widespread, and most annoying form of irritation. The owners of dogs given to spend the hours of darkness in assiduous howling, appear generally to regard with a serene personal imperturbability the noisy nuisance which makes night hideous for their neighbours. Nevertheless, those who keep dogs, especially those who do so in populous places, ought to feel bound to take the simple precautions which alone are necessary to prevent a troublesome form of vexation, which is really a serious source of inconvenience and loss of rest, and possibly of loss of health, to very many people. To the honest bark of a watch-dog giving warning tongue upon suitable occasion no one would object, but the purposeless and unending howling of the chained curs which are especially $N$ prevalent in the suburbs of towns is simply intolerable. It is not necessary to exterminate dogs to put an end to the annoyance in question. The nuisance is perfectly preventable by the adoption of a few simple and sensible measures which, so far from injuring the $N$ offending animals, tend to give them length of days by conducing to their contentment. Those who have had experience in keeping dogs know that these animals will not howl at night if they be comfortable. If dogs, instead of being cruelly chained up out of doors, in kennels which are often draughty and damp, be allowed to have their liberty $\mathscr{Q}$ by day, and to lie within the house at night, they will generally sleep through the night in perfect quietness. Or, if it be necessary to keep a dog chained by day, he ought to be left loose at night, when it will be found that he will retire quietly to his kennel, and abstain from howling, especially if he be furnished with some fresh hay on a clean mat for a bed. In warm weather, dogs howl simply because they want water. Many dogs howl at night because they are kept constantly chained both by night and by day. This is a common and most reprehensible form of cruelty; dogs so treated are sure to be restless and irritable, and can scarcely be healthy. (British Medical fournal, 1883 ;ii :440.) .

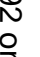

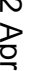

